\title{
BIRDS
}

\section{OBSERVATIONS OF YELLOW RAILS IN SOUTHERN SASKATCHEWAN - 1998 AND 1999}

BOB LUTERBACH, \#217 - 10 Michener Drive, Regina, SK S4V 1R2

Yellow Rails are rare, secretive birds that breed within dense, mature sedge meadows with stable levels of shallow water. Abundant seasonal precipitation and exceptional local flooding in 1999 combined to create excellent breeding habitat for this species.

Yellow Rail vocalizations consist of distinctive, rhythmical clicking sounds. It is often possible to elicit a vocal response by tapping two small stones together to mimic these sounds. Yellow Rails may be heard calling at any time of the day; however the best time is after dusk. They usually continue to vocalize throughout the night unless it is very cool, raining or extremely windy. This elusive species is very difficult to observe without disturbing or harassing the birds; they are best identified by listening for their unique calls.

\section{Northwest Qu'Appelle Valley - 1999 and 1998}

Each spring, a significant portion of the Qu'Appelle Valley along Highway 99 is flooded. This is a result of the combined effects of high volumes of spring runoff, that overwhelm the Qu'Appelle River channel, and the creation of several temporary manmade dams. These dams ensure extensive flooding, which enhances the development of lush pasture lands, hay flats and marshy areas. Typically, this is a brief event; dams are removed, flows subside and the water either quickly evaporates or drains back within the channel. In 1999, exceptional volumes of melt water plus above average seasonal precipitation combined to cause more extensive and prolonged flooding, which continued throughout the summer and early fall.

On June 20, 1999, I undertook my second annual Yellow Rail census northeast of Craven along Highway 99 within the Qu'Appelle Valley. This road extends 21 kilometres southwestward from its junction with Highway 6 to its junction with Highway 322 at Craven. I conducted the survey between midnight and 3:00AM to minimize the potential interference of vehicular traffic. I began the census at the most eastern point, near the junction of Highway 6 , and continued southwestward, stopping every quarter kilometre to listen for the birds. I was surprised to find more than 30 Yellow Rails scattered at the roadside along the northern edge of the Qu'Appelle River flood plain. These spontaneously calling birds were located mainly along the eastern half of this route, beginning near Highway 6 , and ending approximately at the midpoint of the highway near the property called The Spruce Farm. It was difficult to determine accurately just how many rails were present from this point westward because of the proximity of houses, barking dogs and the greater distance of potential habitat from the road. 
Large numbers of Le Conte's Sparrows and Sedge Wrens were also heard during the survey along the eastern half of this route. These two species often are found in association with Yellow Rails. In addition, Sharptailed Sparrows, Marsh Wrens and Sora Rails were located in adjacent habitats of deeper water where Reed Grass (Phragmites australis) or Cattails (Typha sp.) grow. There seemed to be little overlap between these species and the Yellow Rail, Le Conte's Sparrow and Sedge Wren territories.

On June 13, 1998, when I surveyed the same route, I heard only a few small concentrations and not more than 10 Yellow Rails in total. The majority of these birds were located within a roadside oxbow at the extreme northeastern part of this route, near the junction with Highway 6. Several other Yellow Rails were calling a few kilometres farther west in two small, boggy, spring-fed meadows. In 1998, the annual spring flood was less extensive than average, and persisted for only a brief interval. Summer rains were infrequent and light. Much of the area was dry throughout late spring and summer.

\section{Qu'Appelle Valley - Southern Slope}

Every year, for at least 10 years to my knowledge, a small, stable population of Yellow Rails has been present along the southern edge of the valley floor adjoining the Old Catley Ranch. ${ }^{a}$ Each summer, the Regina Natural History Society schedules several field trips to visit this area. The rails usually are concentrated just outside of the property fence, among the upper sedge meadows and fens created by the outflow of several permanent springs which trickle down through the property. The specific location of these Yellow Rail territories is dependant upon the amount of flow. Sometimes they are displaced to the margins of this habitat by high water. Generally, the slope of these wet meadows provides enough drainage to maintain constant water levels. These elevated shallow basins also provide stable water conditions during intervals of reduced flows.

\section{Wascana Creek at Tyvan - 1999 and 1998}

On June 27,1999 , six or so Yellow Rails were heard calling at night in a pasture along a channel of Wascana Creek in the Tyvan area. This pasture, which has many interconnected grassy depressions or swales, initially flooded because the abundant spring run-off could not be contained within the small creek channel. Significant areas of this pasture continued to be flooded throughout the summer. Above average rainfall continually recharged and maintained water levels. In contrast, during 1998 both spring melt water and summer precipitation were below average. There was only a residual amount of water within the main channel. No Yellow Rails were present.

In summary, 1999 probably was a banner year for Yellow Rails in southern Saskatchewan due to the combination of exceptional spring flooding and abundant seasonal precipitation. This is in stark contrast to the drier conditions of 1998 when there were fewer Yellow Rails within the Qu'Appelle Valley area and none at Tyvan. This dynamic species appears capable of the opportunistic movements to take advantage of changing local conditions. This is a predictable strategy for a species which has such specialized habitat requirements. A small, more stable population of Yellow Rails may be found annually within the permanent spring-fed meadows adjoining the Old Catley Ranch. Yellow Rails have been designated as endangered or threatened species within several 
nearby northern States. Saskatchewan populations levels are at this point unknown.

a The Catley property is located along the south slope, directly across the valley from the midpoint of Highway 99. Specific directions and instructions for seeking permission to enter this restricted area may be obtained by contacting Robert Kreba (787-2807) or Bob Luterbach (790-8364).

\section{SOME BIRD OBSERVATIONS IN MANITOBA IN 1999}

BILL KOONZ, Wildlife Branch, Manitoba Conservation, Box 24, 200 Saulteaux Crescent, Winnipeg, MB R3J 3W3

\section{Long Point - June 1}

On June first, Robert Jones (retired bird biologist) and I visited the Gull Bay Sand Spit on the south side of Long Point, Manitoba $\left(52^{\circ} 58^{\prime} \mathrm{N}, 98^{\circ} 54^{\prime} \mathrm{W}\right)$. Long Point sticks out into the west side of Lake Winnipeg near its north end. The sand spit has been growing southwestward for over 30 years. It had attained a length of over 6 kilometres and was nearly a kilometre wide in places before being cut off at the base by lake currents in the spring of 1998 . This spit had been home for a huge Caspian Tern colony in the 1970s when it also had been an island'. Its broad beaches have provided nesting sites for one of the two largest known Piping Plover breeding areas in Manitoba. It was established as the Walter Cook Special Conservation Area by Manitoba Order in Council in 1991. Walter Cook (now deceased), a lifelong Grand Rapids trapper, hunter, fisherman and naturalist, was the first Manitoban to recognize the area as important for nesting Piping Plovers. By the spring of 1999 , the spit had already become a breeding colony for over 2,000 Ringbilled Gull and 2,000 Common Tern pairs. Over 60 Herring Gull nests also were counted there in 1999. Most of the shorelines are eroding, reducing the habitat available for Piping Plovers, but 14 were recorded there on 1 June. Of special interest was the observation of an adult male Lark Bunting recorded on the spit. It was enough of a treat to see Common Grackles, Red-winged Blackbirds, Brown-headed Cowbirds and Brewer's Blackbirds in the same shrub, but having the Lark Bunting there as well made it even more exciting.

\section{Lake Winnipegosis - June 4-11}

On June 4 to 11 , I took part in a boat cruise to count the numbers of nesting colonial waterbirds on Lake Winnipegosis. Participants also included John Weier (author and bird watcher), Don Campbell (retired provincial government photographer) and Doug and Harvey Brown (the captain and his son). Some of the highlights included five Great Blue Heron nests on the ground, a Bald Eagle 